\title{
Diverse Classrooms: Social Justice, Equity, and Diversity Competencies for Teacher Candidates
}

\author{
William S. Ankomah ${ }^{1, *}$ \\ ${ }^{1}$ Faculty of Education, Brock University, St. Catharines, Canada \\ *Correspondence: Faculty of Education, Brock University, St. Catharines, Canada. E-mail: \\ william.ankomah@brocku.ca
}

Received: February 10, 2020

Accepted: March 6, 2020 Online Published: March 11, 2020

doi:10.5430/wje.v10n2p15

URL: https://doi.org/10.5430/wje.v10n2p15

\begin{abstract}
This study explored social justice education literature to argue for greater emphasis on equity and diversity courses in teacher education. Global migration has changed the demographics of Western schools, which more than ever are racially, sexually, and culturally diverse, requiring well-prepared teacher candidates who can support their future students' diverse needs. The author argues that teacher candidates exposed to in-depth social justice, equity, and diversity courses will develop competencies to help them better understand and apply the concepts of social justice, equity, and diversity. Also, teacher candidates will better understand students' academic progress, the teacher's role as an agent of change in the classroom, and students' heightened awareness of power, privilege, and oppression.
\end{abstract}

Keywords: social justice, education, teacher candidates, diversity, equity

\section{Introduction}

As a social justice oriented educator and scholar, the author is excited to witness some social justice-related topics - such as equity, diversity, inclusivity, anti-racism, and cross-cultural and Indigenous education - that already form part of the curriculum offered to teacher candidates (Convertino, 2016; Goodreau \& Fredua-Kwarteng, 2006; Mills \& Ballantyne, 2016). Recent studies of teacher education programs reveal that some teacher educators in Canada and abroad already are teaching for social justice (Convertino, 2016; Daniel, 2009; Lee, 2014; Lemley, 2014; Mills \& Ballantyne, 2016; Powers \& Duffy, 2015). Such course offerings are a welcome development given the diverse ethnic, social, cultural, religious, economic, and political backgrounds of today's K-12 students and teachers (Barker, 2019; Cho, 2010; Daniel, 2009; Faez, 2012). Whatever the impetus for such programming, it is commendable since Western classrooms are no longer homogenous but rather increasingly diverse (Barakett \& Cleghorn, 2008; Barker, 2019). In addition to contributing to the body of literature that seeks to expand equity, diversity, and inclusivity across educational fields, the author makes a case for teacher education programs to actively foster the teaching and learning of equity, diversity, and social justice in teacher candidates' programs. Given that, the paper's guiding question is: How will a greater emphasis on equity, diversity, and social justice courses foster teacher candidates' competencies when working with diverse students in their future classrooms? Intersectionality and critical theoretical lenses are used in this paper to argue that teaching equity, diversity, and social justice to teacher candidates may have significant implications in the latter's future work upon accreditation.

The paper draws from social justice education literature to argue for greater emphasis on equity, diversity, and social justice courses in teacher education programs. Teacher education is the stage during which prospective teachers receive the necessary pedagogical knowledge, skills, and values they will need to become successful professional teachers (O'Neill, 1986; Rowntree, 1981). This level of the education process is crucial in that it is at this stage that teacher candidates are taught, coached, trained, facilitated, and socialized about the dos and don'ts of the teaching profession. Teacher candidates not only are taught how to use different teaching methods (e.g., discussion, inquiry, and role-play) to facilitate the learning of their future students but are also given the opportunity to practice the art and science of teaching under the mentorship of an associate teacher (Sewell, Hansen, \& Weir, 2017; Volante \& Earl, 2002). The increasing diversity of $\mathrm{K}-12$ schools in Western societies places a moral obligation on teacher education programs to support teacher candidates with effective tools to help them navigate the challenges that come with diverse classrooms (Hayden \& Gratteau-Zinnel, 2019; McClanahan \& Buly, 2009). Regarding the challenges of diverse 
classrooms, Alsubaie (2015) observes that students and teachers alike must be able "to navigate unfamiliar people, their cultures, and language" (p. 86) and suggests that trust may be an issue in multicultural classrooms because students and teachers come from different backgrounds that influence not only their interests and values but perhaps also their readiness to learn and teach, respectively. Given the significant role teacher education programs play in preparing future teachers for diverse classrooms, the author believes that the current demographic composition of $\mathrm{K}-12$ students requires competent teachers who are knowledgeable in the subject matter and also willing to uphold and apply equity, diversity, and social justice to create safe and welcoming spaces for all their students.

In her article titled "Diverse Teachers for Diverse Students: Internationally Educated and Canadian Born Teachers' Preparedness to Teach English Language Learners," Farahnaz Faez (2012) argues for the admission of more diverse students in teacher education programs to help train teachers who may better understand the needs of the diverse K-12 student population. The author agrees with Faez because global migration is causing the resettlement of different racial, ethnic, and cultural groups in other parts of the world (Barakett \& Cleghorn, 2008; Titu, Ring-Whalen, Brown, \& Roehrig, 2018). Given the steady global migration, this paper adds to the call for teacher education programs to be active in admitting diverse teacher candidates who may better support students who come from similar backgrounds (Faez, 2012; Titu et al., 2018). On their part, Barakett and Cleghorn (2008) succinctly note that the

diversity of the student population makes it more important than ever before for teachers to be educated and prepared to teach children who may bring to the learning situation many different kinds of prior experiences stemming from their varied social class, language, and cultural backgrounds. (p. 2; emphasis in original)

The point these scholars are making is crucial because Western schools are no longer homogenous in relation to factors such as race, ethnicity, and socioeconomic status. Instead, contemporary Western classrooms are filled with students from diverse backgrounds-learning with and from each other. To Barakett and Cleghorn, substantial diversity and equity education in initial teacher education programs are needed not only to boost the confidence of teacher candidates but also to equip them with competencies they will need to offer their best to the diverse students they will be teaching when accredited. The focus of this paper, therefore, is in line with the findings of scholars who advocate greater and quality instructional time for teacher candidates to help them develop equity, diversity, and social justice competencies for their future work with diverse students. The author argues that teacher candidates should understand the theory and practice of equity, diversity, and social justice so they could enact these concepts when they get the opportunity. The following section explores the two theoretical lenses that influence the discussions presented in this paper.

\section{Theories Informing the Discussion}

\subsection{Intersectionality}

Intersectionality theory originated from critical legal studies, critical feminism, and critical race theory in 1989 (Carastathis, 2016; McCall, 2005) "to address the fact that the experiences and struggles of women of colour fell between the cracks of both feminist and anti-racist discourse" (Davis, 2008, p. 68). Kimberlé Williams Crenshaw, a Black feminist and a legal scholar, is widely credited with advancing intersectionality theory in her 1989 paper titled "Demarginalizing the Intersection of Race and Sex: A Black Feminist Critique of Antidiscrimination Doctrine, Feminist Theory and Antiracist Politics" (Carastathis, 2016; Davis, 2008; Zwier \& Grant, 2014). The introduction of intersectionality theory into legal studies and in feminist and critical race discourses in 1989 marked a watershed moment for Black feminist scholars and activists who over the years had felt a high sense of alienation from mainstream feminism dominated by White women and antiracism discourse dominated by Black men (Carbado, Crenshaw, Mays, \& Tomlinson, 2013). In the seminal paper, Crenshaw (1989) argues for a theory that recognizes the interplay of Black women's sex and race as determining conditions that combine to subordinate the experiences of Black women in feminist and antiracist discourses. Crenshaw (1989) theorizes intersectionality as the lens to use in instances where specific attributes of individuals determine their life chances. In her argument, Crenshaw (1989) claims that "because the intersectional experience is greater than the sum of racism and sexism, any analysis that does not take intersectionality into account cannot sufficiently address the particular manner in which Black women are subordinated" (p. 140). Basically, Crenshaw urges movements and institutions (including schools) to consider the intersections of numerous variables (e.g., colour, sex, ability, and sexual orientation) when formulating and implementing policies and procedures, because such intersections often determine individuals' social location as well as the privilege or exploitation they experience.

On their part, Grant and Zwier (2012) and Zwier and Grant (2014) discuss the slow introduction of intersectionality 
theory into education. In their review of multicultural and social justice literature related to schools, Grant and Zwier (2012) identify two significant aspects of intersectionality: (a) "questions and problems beg to be conceptualized and analyzed through more than one axis" and (b) any "gaps in students' academic achievement are located along more than one axis" (p. 2). In this sense, problems such as student poverty, the school-to-prison-pipeline, and colour-blind policies can be holistically redressed when such a framework is applied to reveal the intersecting elements across the multiple sites of privileging or disenfranchising of students. Defining intersectionality theory, Carastathis (2016) argues that "properly recontextualized, intersectionality represents the condensation of social-movement and critical academic knowledges, motivated by insurrectionary intentions, transformative visions, and collective struggles" (p. 17). Carastathis' view represents a shift from intersectionality theory used merely to name intersections of identity categories and showing how they oppress or privilege an individual, to a more coalitional (Crenshaw, 1991) approach of scholars, educators, and activists working together to dismantle oppressive conditions that subordinate vulnerable and minority groups. Thus, teacher candidates' knowledge of intersectionality can help them understand the various attributes that define their students and colleagues. Such understanding can give them the tools to work in concert with others (e.g., administrators, colleagues, students, and parents) to enhance and support all students' development and learning and stamp out injustices encountered at different sites. Also, teacher candidates with intersectionality and social justice backgrounds can appreciate the need to work together with colleagues and students to transform, for example, racism, sexism, ableism, and homophobia that are present in diverse classrooms but remain difficult conversations (Agyepong, 2010; Lindo, 2013; West-Burns, Murray, \& Watt, 2013) and often, taboo subjects.

Carastathis (2016) and Crenshaw (2015) recognize the conservative backlash on identity politics associated with intersectionality theory. Crenshaw (2015) responds to critiques of identity politics by arguing that "intersectionality is not just about identities but about the institutions that use identity to exclude and privilege" (para. 7) individuals and groups based on their diverse background. To Crenshaw, intersectionality theory and identity politics are needed in situations where individuals and groups are excluded and denied equal and equitable opportunities due to, for example, the colour of their skin, sex, religion, and sexual preference. Again, Crenshaw suggests that intersectionality equips scholars, policymakers, and society in general with an understanding of "how identities and power work together from one context to another" (para. 7) to exclude disenfranchised folks. For both Carastathis and Crenshaw, intersectionality has the potential to advance and solidify the desire of social justice movements for emancipation and transformation of subordinated individuals and groups in society. The second and final theoretical lens used in this paper is critical theory.

\subsection{Critical Theory}

Critical theory dates back to the 1930s and is one of the many interpretivist theories advanced to question and critique the positivists' paradigm (Scott \& Usher, 1996). Max Horkheimer, Herbert Marcuse, and Jürgen Habermas are some of the Frankfurt scholars credited with critical theory (Scott \& Usher, 1996; Stirk, 2000). Scott and Usher (1996) explain that critical theory deals with research and practice that emphasizes "freedom, justice, and democracy" (p. 22), a stance supported by Tilley (2016) who notes that critical theory is emancipatory and focuses on social justice issues. Dell'Angelo, Seaton, and Smith (2014), in turn, assert that the goal of critical theory "is to identify factors that limit human freedom and then to carry out a plan of action to overcome such factors" (p. 2). In other words, Dell'Angelo et al. believe that critical theory can give teachers tools to help them identify and reform the education system's inherent injustices (e.g., racism, sexism, and homophobia) and establish safe and equitable teaching and learning environments for all students to thrive. On their part, Freeman and Vasconcelos (2010) suggest that:

Critical theory is an integral part of building and sustaining a more just society, one in which all members of that society feel empowered to carry out their practices in ways that foster democratic and empowering processes and outcomes, while continuously monitoring those processes and outcomes for evidence of social injustices. (p. 8)

Freeman and Vasconcelos's explanation of critical theory is that in a just society, members of the collective are empowered and equipped with the resources they need to construct a democratic society in which the rights of individuals and groups are respected. Also, to these scholars, using a critical theoretical lens means that the new status quo or way of doing things is continuously critiqued and revised to ensure that equality, equity, and inclusivity are sustained and fostered for the freedom and development of the individual and the collective.

In short, critical theorists seek to emancipate the oppressed by theorizing with action-that is, praxis (Scott \& Usher, 1996; Stirk, 2000). Critical theory, intersectionality, social justice, equity, and diversity thus have a common purpose: to eliminate injustices perpetrated in policies and practices of various organizations, including educational 
institutions and society in general. Given that premise, the author believes that teacher education programs could double their efforts at teaching equity, diversity, and social justice courses, highlighting the essence of intersectionality and critical theoretical lenses to teacher candidates. In the next section, the author responds to the paper's guiding question.

\section{Responding to the Paper's Guiding Question}

The guiding question of the paper is: How will a greater emphasis on equity, diversity, and social justice courses foster teacher candidates' competencies when working with diverse students in their future classrooms? Following, the author has meticulously identified four competencies teacher candidates exposed to in-depth equity, diversity, and social justice may develop before accreditation:

\subsection{Better Understanding and Application of the Concepts of Social Justice, Equity, and Diversity}

The paper argues that greater emphasis on social justice, equity, and diversity courses in teacher education programs will result in teacher candidates understanding these concepts better before they become fully developed teachers. The reason is that scholars such as Celeste (2016), DeLuca (2012), Silverman (2010), and Solomon, Levine-Rasky, and Singer (2003) found that concepts such as equity, diversity, and inclusivity are often misunderstood, misapplied, and conflated by practitioners. Therefore, it is not surprising when teachers engage in a conversation with colleagues who misinterpret these concepts (Lopez, 2013; Solomon et al., 2003), an indication that they are putting square pegs in round holes, and believing that they are right about their interpretation. Given that premise, there is an urgent need for teacher education programs to redesign their curriculum to not only teach these concepts but also ensure that teacher candidates understand the meanings and applications of them. The following section provides some examples of the definitions of social justice, equity, and diversity that can be modified and used in teacher education programs.

Adams and Bell (2016) explain social justice as a concept that "involves eliminating the injustice created when differences are sorted and ranked in a hierarchy that unequally confers power, social, and economic advantages, and institutional and cultural validity to social groups based on their location in that hierarchy" (p. 4). According to these scholars, the status quo of society hierarchizing and administering assistance to individuals based on background continues to devastate individuals and groups who are at the lower end of the "artificial" hierarchy and power continuum. As a result, social justice is about eliminating injustices and reconstructing society to give individuals the needed support to live, work, and enjoy fulfilling lives devoid of discrimination, and balancing the power dynamic in the process. To that effect, Adams and Bell (2016) argue that the existence of injustices calls for a reconstruction of society "in accordance with principles of equity, recognition, and inclusion" (p. 4). Reconstructing society implies that existing institutional frameworks and systems supporting them are problematic (i.e., unjust and exclusionary) and need to change for the good of every individual. Although the zeal for reconstruction is reassuring, such rebuilding is fraught with challenges and a pervasive societal sense of denial in relation to climate change (Dunlap \& McCright, 2010, 2011), racism (Dovemark, 2013; Solomona, Portelli, Daniel, \& Campbell, 2005; Van Dijk, 1992; Watkins, 2016), or sexism (Lykke, 2016). Still, while Adams and Bell (2016) remind scholars that "working for social justice in a society and world steeped in oppression is no simple feat" (p. 4), perseverance among social justice activists and educators may engender better conditions both for the individual and society.

Dell'Angelo et al. (2014), in turn, describe social justice as "recognizing and acting upon the power that we have for making positive change" (p. 1). Dell'Angelo et al.'s description gives social justice educators and critical pedagogues the foundation to promote change when they identify practices that disenfranchise students as a result of their background. According to these scholars, individuals and groups (including perpetually oppressed groups, such as Black people and racialized women) have enormous power in which they can actively find and use it to secure social, economic, cultural, and political justice to enhance their life chances. Like Adams and Bell (2016), Dell'Angelo et al. argue that injustices derail the development of society, making it relevant for social justice educators and activists to mobilize the powers of both privileged and disenfranchised folks for a change that can benefit all students and educational stakeholders. In this regard, this author believes that the school-an environment in which diverse groups of people interact perhaps the most - should embrace social justice to enable students (future leaders) to develop their potentials without any racial, sexual, and political constraints. Such acceptance could be possible and enhanced when teacher candidates understand the reasons behind social justice initiatives in which injustices and inequities are confronted and dismantled to create safe spaces for every student in the classroom and the school system. Other scholars (e.g., Bartolome \& Macedo, 2017; Dei, 1999; Solomon et al., 2003) point out systemic issues-colour blindness, streaming, school-to-prison pipeline - present in culturally diverse institutions and often encountered by marginalized students as an imbalance of power that may be alleviated by strengthening the knowledge base of teacher 
candidates to social justice praxis. In this paper, social justice is operationalized as a process in which equitable practices are applied at all times, and respect for human rights and dignity are promoted and upheld. In an educational context, social justice is expressed as an umbrella term used to foster unity in diversity that ensures that equity, diversity, and inclusivity are respected, promoted, and supported among all students, staff, teachers, and parents irrespective of their backgrounds (Colleague \& Author, 2019).

Equity in education continues to evolve and is often conflated with equality, and therefore the concept can be misapplied (DeLuca, 2012). Cochran-Smith et al. (2016) remind us that equity is "primarily to do with fairness and justice" (p. 69), an explanation that may be tricky to many teachers. The reason is that fairness and justice denote equal treatment irrespective of one's particular needs. In other words, Cochran-Smith et al.'s position on equity suggests that all students must be given the same support in the education system. The confusion is that many educators believe that fairness in the classroom means equity (Celeste, 2016; Solomon et al., 2003), an understanding that leads such teachers to misapply these concepts (DeLuca, 2012; Solomon et al., 2003). Explaining equity, Lopez (2013) suggests that "equity is not about giving each student the same"; instead, it "demands different treatment of students according to their needs" (p. 299). To Lopez, equity is not the same as equality because equality does not consider individual differences, needs, and aspirations but instead applies the principles of homogeneity to individuals in a group. However, equity seeks to provide every student with differentiated support and adequate resources to bring out the best in them. Equity caters to individual differences, a crucial concept that teacher candidates should understand, so they do not enact equality and assume they were equitable in their practice. As students come from diverse backgrounds, they have different needs or gaps to fill (Celeste, 2016) to develop their full potentials. Therefore, upholding the equality of humans in terms of everyone being equal but applying equity in the classroom to guarantee that every student receives what is relevant for their progress and success is the equity this paper espouses. In line with that, this author sees equity as an ongoing process aimed at supporting individual students with specific things - tangible and intangible - they need to develop their full potential. As a process and a work-in-progress praxis, for example, teachers provide extra tutoring, homework, or direction to students who require more assistance and challenge their high achieving students to get to the next level. In addition, teachers with equity skills can actively help provide ergonomic supplies and support to students when they observe that there is such a need.

Adams and Bell (2016) explain diversity as "differences among social groups such as ethnic heritage, class, age, gender, sexuality, ability, religion, and nationality. These differences are reflected in historical experiences, language, cultural practices, and traditions that ought to be affirmed and respected" (p. 3). Adams and Bell's point is that there is diversity present in our society that manifests in race, gender, and culture among others. Therefore, teacher candidates' better understanding of the differences between and among their learners may support their work when they find themselves in the classroom as accredited teachers. Through a critical examination of how these variables intersect to benefit or deprive an individual or a group, teachers with in-depth social justice, equity, and diversity knowledge will be in a better position to help students recognize and respect others who embody the differences they do not share. In addition, teacher candidates' in-depth knowledge, skills, and values in social justice, equity, and diversity issues and initiatives may help them better understand themselves in relation to their colleagues and students. Such understanding can lead to the affirmation that "difference is not wrong," motivating everyone in the class to work together to support each other's learning.

In 1999, the University of Oregon established a Diversity Steering Committee to develop a working definition of the concept of "diversity." After two decades, the explanation offered by the committee is still relevant and worth quoting extensively:

The concept of diversity encompasses acceptance and respect. It means understanding that each individual is unique, and recognizing our individual differences. These can be along the dimensions of race, ethnicity, gender, sexual orientation, socio-economic status, age, physical abilities, religious beliefs, political beliefs, or other ideologies. It is the exploration of these differences in a safe, positive, and nurturing environment. It is about understanding each other and moving beyond simple tolerance to embracing and celebrating the rich dimensions of diversity contained within each individual. (University of Oregon, 1999, para. 1)

The committee's definition underscores the differences among people, touching on recognizing and respecting everyone's worth. In school contexts, students, teachers, and staff who care about human development can make efforts to not only embrace the representation of diverse people in their shared space but also actively respect, celebrate, and support the welfare of each other, allowing them the freedom to thrive. From the preceding discussions, it is clear that social justice, equity, and diversity are interrelated concepts that aim at human liberty and development. Also, all of these concepts focus on the greater well-being and freedom of the individual, group, and 
society in general; as a result, it is appropriate to ask teacher education programs to double their efforts in helping teacher candidates develop competencies that will help them to better support their future diverse students.

\subsection{Better Understanding of Students' Academic Progress}

Critical theorists suggest that knowledge is socially constructed and reject positivists' stance on the objectivity of knowledge (Darder, Baltodano, \& Torres, 2017; Scott \& Usher, 1996; Sensoy \& DiAngelo, 2017). As a product of social construction, knowledge cannot be seen as absolute but rather something that can be manipulated or revised to suit current needs and particular contexts (Sensoy \& DiAngelo, 2017). As a result, teacher education programs can place greater emphasis on social justice, equity, and diversity courses in their programs to highlight the need for teacher candidates to be open to new ideas and contributions from their students and colleagues when they begin their teaching careers. The education system should not forget that teacher candidates also come from diverse backgrounds (Ryan, Pollock \& Antonelli, 2009), and have different experiences, worldviews, visions, and biases that are shaped by their cultures and prevailing dominant discourses. Teacher candidates thus need in-depth knowledge about all the concepts that are the focus of this paper to develop competencies that will enable them to accept their future students the way they are, without prejudices and preconditions. With an intersectionality theoretical lens, teacher candidates will have the courage to devise better strategies and appropriate pedagogies to equitably support the diverse needs of every individual student. For example, as Grant and Zwier (2012) identified, intersectionality views and analyzes gaps in individual student achievement through more than one axis. Questions such as the following could be asked to understand and remedy root causes of students' low academic performance: Could their low achievement be caused by both institutional racism and sexism, and if so, how can we implement effective programs to help affected students? How much of a student's accomplishments or otherwise be attributed to the intersections of race, sex, sexual orientation, and religious affiliation? As a teacher, what is my role in implementing racial, sexual, and economic justice for all my students irrespective of who they are or where they come from? Here, the argument is that the exposure of teacher candidates to in-depth social justice, equity, and diversity will conscientize these would-be teachers about injustices and inequities in the educational system that fail to consider the multiple sites in which disenfranchised students suffer discrimination and injustices in the school system. This author believes that with greater emphasis on social justice, equity, and diversity courses in teacher education, teacher candidates will be challenged to question their complicity and biases when assessing the academic progress of their future students.

The author also agrees with Dell'Angelo et al. (2014) that many teachers provide all kinds of extra support for students who perform "below average." In other words, some teachers apply the principles of equity to shore up students who require extra support in their learning process; however, it should also be noted that some teachers knowingly or unknowingly use the "hidden curriculum" (McLaren, 2017) to discriminate against students with alternative worldviews. Such teachers may not challenge their disenfranchised students enough due to the prejudice they already have about their academic performance. According to McLaren (2017), the hidden curriculum refers to the unintended outcomes of the schooling process ... the non-subject-related sets of behaviors produced in students ... [and the] learning outcomes not openly acknowledged to students (pp. 70-71; emphasis in original). In other words, the hidden curriculum can be used by teachers who are not skillful at social justice, equity, and diversity initiatives to further disenfranchise students who could have done better if the teacher had motivated them.

Similarly, Raible and Irizarry (2017) argue that "it is clear that teachers play a significant role, for better or worse, in the sorting and labeling of young people once they enter school" (p. 463). Raible and Irizarry's argument in a Foucauldian analysis of power suggests that teachers hold most of the power in educational contexts, and can use the power they command to administer a fair assessment to all students or display bias against some students due to, for example, race and gender. The point here is that teachers should strive to recognize their bias and any personal influence when assessing students (Cochran-Smith, 2004) so they can self-critique and address such negative tendencies. However, this author believes that teachers can to a large degree set aside bias in their work if their teacher education was strong enough in distorting the prejudices they have about different worldviews. That is why more than ever, it behooves teacher education programs to double down their efforts in helping teacher candidates develop social justice, equity, and diversity competencies. For example, teacher candidates with adequate knowledge of social justice will question the meritocratic system entrenched in assessment (Cochran-Smith, 2004; Harber, 2009) - a system in which students' failure to make a certain grade results in such "underachievers" being excluded not only from higher levels of learning but also from a more active and fulfilling role in society as a whole.

In-depth social justice, equity, and diversity training in initial teacher education programming can build critical awareness about the differences and the wealth of knowledge each learner brings to the classroom (Apple, 2017; Yosso, 2005). Students' motivation level can fluctuate with the grades they receive, especially when they perceive injustices in 
the way the grades are assigned. Darder et al. (2017) and Scott and Usher (1996) assert that critical theory is interested in processes that are devoid of structural and ideological inequalities, a position endorsed in this paper. The position of the teacher in knowledge creation, discovery, transmission, facilitation, and assessment is a privileged one, and adequate knowledge of social justice, equity, and diversity may help teacher candidates to better understand and support students' academic progress when they enter the field as practicing teachers.

\subsection{Better Understanding of the Teacher's Role as an Agent of Change in the Classroom}

Daniel (2009) and DeLuca (2012) argue that teachers introduced to social justice, equity, and diversity education understand that they need to critically reflect on their actions, behaviours, and attitudes towards "others," and do likewise for the institutions that employ them. Such reflexivity is warranted when juxtaposed with the discrimination, bullying, and oppression of some students and groups of students in the school system (Baily \& Katradis, 2016; Lee, 2011). An assessment of the ideologies and policies (e.g., colour-blind policies) that shape a teacher's work may reveal instances of inequalities and inequities (e.g., streaming racialized students to applied rather than academic courses) in the system within which the teacher operates. Meanwhile, the education system that welcomes students of diverse backgrounds supposedly is designed to be fair and equitable to every student (Ontario Ministry of Education, 2017, Ensuring Equity section), but, for example, antiracism scholars such as James $(2010,2012)$ disprove that because racism and discrimination against racialized students are still present in Western schools. Given the continuous injustices in school systems, Blake (2015) reminds scholars that the classroom and the school itself traditionally have been platforms of change, with teachers acting as change agents. Therefore, as articulated in this paper, teacher candidates need to be prepared fully to understand and embrace their unofficial role as agents of change. This author believes that quality social justice, equity, and diversity courses in teacher education programs could be one of the answers to stamping out injustices and inequities from the classroom. Teacher candidates' competencies in these concepts could make them effective role models who would use their understanding of injustice to initiate significant changes (e.g., by modeling inclusive practices and motivating students to critique their own beliefs and assumptions about the "other") to create safe and welcoming spaces for every student. Again, Adams and Bell (2016) conscientize educators and scholars to play active roles in reconstructing the school to promote and enact equity in its day-to-day practices. Like Adams and Bell, Blake (2015) and Darder et al. (2017) also believe that teachers who receive social justice, equity, and diversity education as part of their initial teacher preparation will become agents of change for the good of the students and society as a whole.

Preparing teachers to be capable and willing to confront and question injustices in existing school policies and practices that overtly or covertly limit oppressed students and groups' ability to enjoy the full benefits of attending school should be one of teacher educators' primary goals. Teacher candidates with adequate knowledge of social justice, equity, and diversity may be in a better position to hold respectful and constructive dialogue with students, colleagues, and administrators who may subject "others" to racism, sexism, classism, or homophobia. Critical theory thus positions teacher candidates to apply the diversity, equity, and social justice theories learned during their teacher education in their classrooms and schools (Darder et al., 2017; Scott \& Usher, 1996). In other words, the theory learned will be practiced for the benefit of all students.

Also, as agents of change, teacher candidates will have a solid foundation of social justice, equity, and diversity knowledge to support their students through critical self-reflexivity and constant critique of the status quo in order to bring down all forms of domination (Darder et al., 2017) that mar the schooling experience of minority students. On the other hand, intersectionality asks that all the multiple identities in an individual are considered when formulating new policies or making changes to existing ones because it is the intersection of these identities that unleashes injustices on oppressed people. Noguera and Torres (2008) and Russo (2004) believe that when teacher candidates learn social justice, they will be able to disrupt and transform the oppression that vulnerable students encounter, which may build a safer classroom for all students irrespective of their background.

\subsection{Better Knowledge about Students' Heightened Awareness of Power, Privilege, and Oppression}

The proliferation of social media outlets (e.g., Facebook, Instagram, WhatsApp, Twitter) along with the continuous spread of traditional radio and television media have opened up the debate on social justice, equity, and diversity issues and initiatives in the public domain. Bartolome and Macedo (2017) put the scope and influence of the media into perspective, noting that "the popular press and the mass media educate more people about issues regarding ethnicity and race than all other sources of education available to U.S. citizens" (p. 196). With that observation, Bartolome and Macedo remind educators and scholars about the media's enormous influence on students and society and the need for teachers to actively use the knowledge acquired by learners through the media (i.e., traditional and social media outlets) to foster students' curiosity and learn positively. On their part, Darder et al. (2017) argue that critical media literacy and critical dialogue "encompass a pedagogical process of teaching and learning, by which students and teachers 
interrogate the world, unmask ideological and hegemonic discourses, and frame their actions, in the interest of the larger struggle for social justice" (p. 367). In other words, Darder et al. believe that teachers who are exposed to social justice and have knowledge of critical theory and critical pedagogy know the injustices inherent in the media consumed by students. As a result, such teachers are better prepared to assist their learners through critical media literacy and critical dialogue to question the merits in what they hear, see, and participate in for better decision-making.

Aronowitz (2017) argues that "young people learn, for ill as well as good, from popular culture (especially music), from parents, and, perhaps most important, from their peers" (p. 120). The essence of Aronowitz's argument is that students are already aware of the injustices present in their classrooms, schools, and society. As a result, teacher candidates with that insight will not be naïve about the knowledge level of their students. In her Teaching Tolerance weblog post, Christina Torres (2015) notes that her students "are not just keen observers of the outside world; they experientially learn from struggles around power and privilege every day. ... It is either mine to acknowledge or ignore" (para. 1). Torres provides the context in which teacher education programs should help teacher candidates strive to develop social justice, equity, and diversity knowledge, skills, and attitudes they will need to assist their partly informed students effectively. Aronowitz (2017), Bartolome and Macedo (2017), Darder et al. (2017), and Torres (2015) all underscore the importance of having well-informed and social justice-minded teachers who can moderate and enact critical dialogue about power, privilege, and oppression in schools and society. Like Torres, Lee (2014) discusses how teachers underestimate what their students know about social justice issues: "students often mask their activities from adults when the activities have negative components of diversity matters" (p. 13). In line with Lee's observation, this author argues that teachers' presumption of the innocence of their students to a more significant extent informs the way they approach their teaching and managing of their class, making the call for greater emphasis on social justice, equity, and diversity courses a worthwhile demand.

As noted above, this author argues that placing greater emphasis on social justice, equity, and diversity education in teacher education will challenge teacher candidates not to assume wrongly or take things at face value. The presumption that students, regardless of their age, are completely unaware and for that matter innocent is erroneous. From the accounts of the scholars whose works have influenced this section, students are aware of power, privilege, and oppression in their schools, homes, and society; therefore, teachers have the responsibility to tap into that knowledge to help students understand their actions and make informed choices. In sum, this author expects that teachers who had in-depth social justice, equity, and diversity education in teacher education programs should become able, ready, and willing to lead a "healthy" discussion with their students by challenging them to critically analyze the implications of what they hear, see, touch, or assume to inform their actions.

\section{Conclusion}

This paper has explored four benefits for teacher candidates exposed to in-depth knowledge of social justice, equity, and diversity courses. First, teacher candidates will develop competencies that would help them better understand and apply the concepts of social justice, equity, and diversity upon accreditation. Second, teacher candidates will better understand the academic progress of their students, helping them to meet the unique needs of each student. Moreover, teacher candidates will better understand their roles as agents of change to help create safe classrooms for their future students. Finally, this paper has argued that teacher candidates exposed to quality social justice, equity, and diversity education will develop better knowledge about students' heightened awareness of power, privilege, and oppression. The list is not exhaustive but it does add crucial points to the discussion about the essence of assisting teacher candidates in developing quality social justice, equity, and diversity competencies before they become accredited teachers in diverse classrooms. It is an understatement to say that teachers are an essential part of knowledge creation and dissemination. Responsibilities put on teachers by ministries of education position the former as parents for the students they teach. Such an obligation requires teachers to be mentally and physically prepared to handle both the overt and hidden injustices in the school system. Hopefully, teacher candidates with greater insight into social justice, equity, and diversity education will be able to apply the knowledge, skills, and values developed during their teacher candidacy, both professionally and passionately, to stand with and for the well-being and freedom of all their students.

\section{References}

Adams, M., \& Bell, L. A. (Eds.). (2016). Teaching for diversity and social justice (3rd ed.). New York, NY: Routledge. https://doi.org/10.4324/9781315775852

Agyepong, R. (2010). Rethinking anti-racism and equity education: Issues of curriculum and development of 
teachers. Our Schools/Our Selves, 19(3), 75-85.

Alsubaie, M. A. (2015). Examples of current issues in the multicultural classroom. Journal of Education and Practice, 6(10), 86-89.

Apple, W. M. (2017). Cultural politics and the text. In A. Darder, R. D. Torres, \& M. P. Baltodano (Eds.), The critical pedagogy reader (3rd ed., pp. 79-94). New York, NY: Routledge. https://doi.org/10.4324/9781315021089

Aronowitz, S. (2017). Against schooling: Education and social class. In A. Darder, R. D. Torres, \& M. P. Baltodano (Eds.), The critical pedagogy reader (3rd ed., pp. 118-134). New York, NY: Routledge.

Baily, S., \& Katradis, M. (2016). "Pretty much fear!!" Rationalizing teacher (dis)engagement in social justice education. Equity \& Excellence in Education, 49(2), 215-227. https://doi.org/10.1080/10665684.2016.1144833

Barakett, J., \& Cleghorn, A. (2008). Sociology of education: An introductory view from Canada (2nd ed.). Toronto, ON: Pearson Education.

Barker, D. (2019). In defence of white privilege: Physical education teachers' understandings of their work in culturally diverse schools. Sport, Education and Society, 24(2), 134-146. https://doi.org/10.1080/13573322.2017.1344123

Bartolome, L. I., \& Macedo, D. P. (2017). Dancing with bigotry: The poisoning of racial and ethnic identities. In A. Darder, R. D. Torres, \& M. P. Baltodano (Eds.), The critical pedagogy reader (3rd ed., pp. 196-215). New York, NY: Routledge.

Blake, C. (2015, May 13). Teaching social justice in theory and practice [Web log post]. Retrieved from http://education.cu-portland.edu/blog/news/teaching-social-justice/

Carastathis, A. (2016). Intersectionality: Origins, contestations, horizons. Lincoln, NE: University of Nebraska Press. https://doi.org/10.2307/j.ctt1 fzhfz8

Carbado, D. W., Crenshaw, K. W., Mays, V. M., \& Tomlinson, B. (2013). Intersectionality: Mapping the movements of a theory. Du Bois Review, 10(2), 303-312. https://doi.org/10.1017/S1742058X13000349

Celeste, E. (2016). What we mean when we say “equity.” The Learning Professional, 37(5), 10-11.

Cho, L. C. (2010). "Qualifying" as teacher: Immigrant teacher candidates' counter-stories. Canadian Journal of Educational Administration and Policy, 100, 1-22. Retrieved from https://journalhosting.ucalgary.ca/index.php/cjeap/article/view/42780/30640

Ciuffetelli Parker, D., \& Ankomah, W. S. (2019). Are we doing it right?: Diversity, curriculum making, and teacher education. In J. Mueller \& J. Nickel, (Eds.), Globalization and diversity: What does it mean for teacher education in Canada? (pp. 290-315). Canadian Association for Teacher Education Working Conference Publications.

Retrieved

from https://cate-acfe.ca/wp-content/uploads/2019/11/Final-Working-Conference-Book-Halifax-2017.pdf

Cochran-Smith, M. (2004). Walking the road: Race, diversity, and social justice in teacher education. New York, NY: Teachers College Press.

Cochran-Smith, M., Ell, F., Grudnoff, L., Haigh, M., Hill, M., \& Ludlow, L. (2016). Initial teacher education: What does it take to put equity at the center? Teaching and Teacher Education, 57, 67-78. https://doi.org/10.1016/j.tate.2016.03.006

Convertino, C. (2016). Beyond ethnic tidbits: Toward a critical and dialogical model in multicultural social justice teacher preparation. International Journal of Multicultural Education, 18(2), 125-142. https://doi.org/10.18251/ijme.v18i2.1074

Crenshaw, K. W. (1989). Demarginalizing the intersection of race and sex: A Black feminist critique of antidiscrimination doctrine, feminist theory and antiracist politics. University of Chicago Legal Forum, 1989, Art. 8, 139-167.

Crenshaw, K. W. (1991). Mapping the margins: Intersectionality, identity politics, and violence against women of color. Stanford Law Review, 43(6), 1241-1299. https://doi.org/10.2307/1229039

Crenshaw, K. (2015, September 24). Why intersectionality can't wait. The Washington Post. Retrieved from https:/www.washingtonpost.com/news/in-theory/wp/2015/09/24/why-intersectionality-cant-wait/?Utm_term=.8 $993 \mathrm{a} 95 \mathrm{f} 243 \mathrm{~d}$ 
Daniel, B. J. (2009). Conversations on race in teacher education cohorts. Teaching Education, 20(2), 175-188. https://doi.org/10.1080/10476210902730497

Darder, A., Baltodano, M. P., \& Torres, R. D. (Eds.). (2017). The critical pedagogy reader (3rd ed.). New York, NY: Routledge.

Davis, K. (2008). Intersectionality as buzzword: A sociology of science perspective on what makes a feminist theory successful. Feminist Theory, 9(1), 67-85. https://doi.org/10.1177/1464700108086364

Dei, G. J. S. (1999). The denial of difference: Reframing anti-racist praxis. Race Ethnicity and Education, 2(1), 17-38. https://doi.org/10.1080/1361332990020103

Dell'Angelo, T., Seaton, G., \& Smith, N. (2014). Critical theory in education. In S. Totten \& J. E. Pedersen (Eds.), Educating about social issues in the 20th and 21st centuries: Critical pedagogues and their pedagogical theories (Vol. 4, pp. 1-34). Charlotte, NC: Information Age.

DeLuca, C. (2012). Promoting inclusivity through and within teacher education programmes. Journal of Education for Teaching, 38(5), 551-569. https://doi.org/10.1080/02607476.2013.739792

Dovemark, M. (2013). How private "everyday racism" and public "racism denial" contribute to unequal and discriminatory educational experiences. Ethnography and Education, 8(1), 16-30. https://doi.org/10.1080/17457823.2012.717199

Dunlap, R. E., \& McCright, A. M. (2010). Climate change denial: Sources, actors and strategies. In C. Lever-Tracy (Ed.), Routledge handbook of climate change and society (pp. 240-259). Abingdon, UK: Routledge.

Dunlap, R. E., \& McCright, A. M. (2011). Organized climate change denial. In J. S. Dryzek, R. B. Norgaard, \& D. Schlosberg (Eds.), The Oxford handbook of climate change and society (pp. 144-160). Oxford, UK: Oxford University Press. https://doi.org/10.1093/oxfordhb/9780199566600.003.0010

Faez, F. (2012). Diverse teachers for diverse students: Internationally educated and Canadian-born teachers' preparedness to teach English language learners. Canadian Journal of Education, 35(3), 64-84.

Freeman, M., \& Vasconcelos, E. F. S. (2010). Critical social theory: Core tenets, inherent issues. In M. Freeman (Ed.), Critical social theory and evaluation practice: New directions for evaluation (pp. 7-19). Hoboken, NJ: John Wiley \& Sons. https://doi.org/10.1002/ev.335

Goodreau, J., \& Fredua-Kwarteng, E. (2006). Integrating equity and social justice into teacher preparation. Retrieved from http://www.oise.utoronto.ca/cld/UserFiles/File/integratingequityandsocialjusticeintoteacherpreparation.pdf

Grant, C. A., \& Zwier, E. (2012). Intersectionality and education. In J. Banks (Ed.), Encyclopedia of diversity in education (pp. 1263-1271). Thousand Oaks, CA: Sage.

Harber, C. (2009). Perpetrating disaffection: Schooling as an international problem. Educational Studies, 34(5), 457-467. https://doi.org/10.1080/03055690802288445

Hayden, E., \& Gratteau-Zinnel, T. R. (2019). Not a moment to lose: Mentoring teacher candidates for new cultures and climate. Mid-Western Educational Researcher, 31(2), 144-165.

James, C. E. (2010). Why is the school basketball team predominantly Black? In S. E. Tozer, B. P. Gallegos, A. M. Henry, M. B. Greiner, \& P. G. Price (Eds.), Handbook of research in the social foundations of education (pp. 450-459). Abingdon, UK: Routledge.

James, C. E. (2012). Students "at risk" stereotypes and the schooling of black boys. Urban Education, 47(2), 464-494. https://doi.org/10.1177/0042085911429084

Lee, Y. A. (2011). What does teaching for social justice mean to teacher candidates? The Professional Educator, 35(2). Retrieved from https://files.eric.ed.gov/fulltext/EJ988204.pdf

Lee, Y. A. (2014). Three cases of student teaching practice for social justice in early childhood education. Journal of Education and Training Studies, 2(4), 12-22. https://doi.org/10.11114/jets.v2i4.489

Lemley, C. K. (2014). Social justice in teacher education: Naming discrimination to promote transformative action. Critical Questions in Education, 5(1), 26-51.

Lindo, L. M. (2013). Engaging in social justice: The diversity project practicum. Education Canada, 54(4), $62-65$.

Lopez, A. E. (2013). Collaborative mentorship: A mentoring approach to support and sustain teachers for equity and diversity. Mentoring \& Tutoring: Partnership in Learning, 21(3), 292-311. 
https://doi.org/10.1080/13611267.2013.827836

Lykke, L. C. (2016). Visibility and denial: Accounts of sexual violence in race-and gender-specific magazines. Feminist Media Studies, 16(2), 239-260. https://doi.org/10.1080/14680777.2015.1061034

McCall, L. (2005). The complexity of intersectionality. Signs, 30(3), 1771-1800. https://doi.org/10.1086/426800

McClanahan, L., \& Buly, M. R. (2009). Purposeful partnerships: Linking preservice teachers with diverse K-12 students. Multicultural Education, 16(3), 55-59.

McLaren, P. (2017). Critical pedagogy: A look at the major concepts. In A. Darder, R. D. Torres, \& M. P. Baltodano (Eds.), The critical pedagogy reader (3rd ed., pp. 56-78). New York, NY: Routledge.

Mills, C., \& Ballantyne, J. (2016). Social justice and teacher education: A systematic review of empirical work in the field. Journal of Teacher Education, 67(4), 263-276. https://doi.org/10.1177/0022487116660152

Noguera, P., \& Torres, C. A. (Eds.). (2008). Social justice education for teachers: Paulo Freire and the possible dream. Rotterdam, The Netherlands: Sense.

O'Neill, G. P. (1986). Teacher education or teacher training: Which is it? McGill Journal of Education, 21(3), 257-265.

Ontario Ministry of Education. (2017). Achieving excellence: Ensuring equity. Retrieved from http://www.edu.gov.on.ca/eng/about/equity.html

Powers, B., \& Duffy, P. B. (2016). Making invisible intersectionality visible through Theater of the Oppressed in teacher education. Journal of Teacher Education, 67(1), 61-73. https://doi.org/10.1177/0022487115607621

Raible, J., \& Irizarry, J. G. (2017). Redirecting the teacher's gaze: Teacher education, youth surveillance and the school-to-prison pipeline. In A. Darder, R. D. Torres, \& M. P. Baltodano (Eds.), The critical pedagogy reader (3rd ed., pp. 461-475). New York, NY: Routledge.

Rowntree, D. (1981). A dictionary of education. New York, NY: Harper \& Row.

Ryan, J., Pollock, K., \& Antonelli, F. (2009). Teacher diversity in Canada: Leaky pipelines, bottlenecks, and glass ceilings. Canadian Journal of Education, 32(3), 591-617.

Russo, P. (2004, June). What does it mean to teach for social justice? Retrieved from http://www.oswego.edu/ prusso1/Russos_what_does_it_mean_to_teach_for_s.htm

Scott, D., \& Usher, R. (1996). A critique of the neglected epistemological assumptions of educational research. In D. Scott \& R. Usher (Eds.), Understanding educational research (pp. 9-32). London, UK: Routledge. ttps://doi.org/10.4324/9780203287941

Sensoy, O., \& DiAngelo, R. (2017). Is everyone really equal?: An introduction to key concepts in social justice education (2nd ed.). New York, NY: Teachers College Press.

Sewell, A., Hansen, S., \& Weir, K. (2017). Enhancing the capabilities of associate teachers in the practicum: A New Zealand case study. New Zealand Journal of Educational Studies, 52(1), 21-39. https://doi.org/10.1007/s40841-017-0078-z

Silverman, S. K. (2010). What is diversity? An inquiry into preservice teacher beliefs. American Educational Research Journal, 47(2), 292-329. https://doi.org/10.3102/0002831210365096

Solomon, R. P., Levine-Rasky, C., \& Singer, J. (2003). Teaching for equity and diversity: Research to practice. Toronto, ON: Canadian Scholars' Press.

Solomona, R. P., Portelli, J. P., Daniel, B. J., \& Campbell, A. (2005). The discourse of denial: How white teacher candidates construct race, racism and "white privilege." Race Ethnicity and Education, 8(2), 147-169. https://doi.org/10.1080/13613320500110519

Stirk, P. (2000). Critical theory, politics and society: An introduction. New York, NY: Continuum.

Tilley, S. A. (2016). Doing respectful research: Power, privilege and passion. Black Point, NS: Fernwood.

Titu, P., Ring-Whalen, E. A., Brown, J. C., \& Roehrig, G. H. (2018). Exploring changes in science teachers' attitudes toward culturally diverse students during an equity-focused course. Journal of Science Teacher Education, 29(5), 378-396. https://doi.org/10.1080/1046560X.2018.1461006

Torres, C. (2015, March 5). Why teaching about social justice matters [Web log post]. Retrieved from 
https://www.tolerance.org/magazine/why-teaching-about-social-justice-matters

University of Oregon. (1999). Definition of diversity. Retrieved from http://gladstone.uoregon.edu/ asuomca/diversityinit/definition.html

Van Dijk, T. A. (1992). Discourse and the denial of racism. Discourse \& Society, 3(1), 87-118. https://doi.org/10.1177/0957926592003001005

Volante, L., \& Earl, L. (2002). Teacher candidates' perceptions of conceptual orientations in their preservice program. Canadian Journal of Education, 27(4), 419-438. https://doi.org/10.2307/1602243

Watkins, D. (2016, September 24). Come clean, racists! Closeted Trump supporters and racism-deniers are a lot more $\begin{array}{lllll}\text { dangerous } & {[\mathrm{Web}} & \log & \text { post }] . & \text { Retrieved }\end{array}$ http://www.salon.com/2016/09/24/come-clean-racists-closeted-trump-supporters-and-racism-deniers-are-a-lotmore-dangerous/

West-Burns, N., Murray, K., \& Watt, J. (2013). Voices of equity: Beginning teachers are crucial partners and emerging leaders of equity education. Journal of Staff Development, 34(6), 34-37.

Yosso, T. J. (2005). Whose culture has capital? A critical race theory discussion of community cultural wealth. Race Ethnicity and Education, 8(1), 69-91. https://doi.org/10.1080/1361332052000341006

Zwier, E., \& Grant, C. A. (2014). Thinking intersectionality in education. In C. A. Grant \& E. Zwier (Eds.), Intersectionality and urban education: Identities, policies, spaces \& power (pp. 3-28). Charlotte, NC: Information Age. 